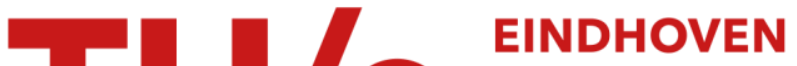

\section{An evaluation of alternative stator lamination materials for a high-speed, 1.5 MW, permanent magnet generator}

Citation for published version (APA):

Paulides, J. J. H., Jewell, G. W., \& Howe, D. (2004). An evaluation of alternative stator lamination materials for a high-speed, 1.5 MW, permanent magnet generator. IEEE Transactions on Magnetics, 4O(4), 2041-2043.

https://doi.org/10.1109/TMAG.2004.832172

DOI:

10.1109/TMAG.2004.832172

Document status and date:

Published: 01/01/2004

\section{Document Version:}

Publisher's PDF, also known as Version of Record (includes final page, issue and volume numbers)

\section{Please check the document version of this publication:}

- A submitted manuscript is the version of the article upon submission and before peer-review. There can be important differences between the submitted version and the official published version of record. People interested in the research are advised to contact the author for the final version of the publication, or visit the $\mathrm{DOI}$ to the publisher's website.

- The final author version and the galley proof are versions of the publication after peer review.

- The final published version features the final layout of the paper including the volume, issue and page numbers.

Link to publication

\section{General rights}

Copyright and moral rights for the publications made accessible in the public portal are retained by the authors and/or other copyright owners and it is a condition of accessing publications that users recognise and abide by the legal requirements associated with these rights.

- Users may download and print one copy of any publication from the public portal for the purpose of private study or research.

- You may not further distribute the material or use it for any profit-making activity or commercial gain

- You may freely distribute the URL identifying the publication in the public portal.

If the publication is distributed under the terms of Article 25fa of the Dutch Copyright Act, indicated by the "Taverne" license above, please follow below link for the End User Agreement:

www.tue.nl/taverne

Take down policy

If you believe that this document breaches copyright please contact us at:

openaccess@tue.nl

providing details and we will investigate your claim. 


\title{
An Evaluation of Alternative Stator Lamination Materials for a High-Speed, 1.5 MW, Permanent Magnet Generator
}

\author{
Johannes J. H. Paulides, Geraint W. Jewell, and David Howe
}

\begin{abstract}
The influence of the choice of stator lamination material on the iron loss in a high speed, high power permanent magnet generator, which is interfaced to a DC link via a simple bridge rectifier, is investigated. The rating of the generator is representative of machines which would be employed in 'more-electric' ships and for embedded power generation. It is shown that the iron loss can be reduced considerably by employing $6.5 \% \mathrm{SiFe}$ laminations rather than $3 \% \mathrm{SiFe}$. It is also shown that, due to the high harmonic content in the phase current waveforms, the iron loss density can vary widely over the stator laminations.
\end{abstract}

Index Terms-Generator, iron loss, permanent magnet, $6.5 \%$ SiFe.

\section{INTRODUCTION}

$\mathbf{T}$ HERE is a growing interest in exploiting the high-speed capabilities and high power densities of permanent magnet $(\mathrm{PM})$ machines in direct-drive, gas-turbine generator sets for applications such as auxiliary power sources in "more-electric" ships and embedded generation plant in power utility systems. Typically, machines for such applications have power ratings in the 1 to $3 \mathrm{MW}$ range and operating speeds up to $20000 \mathrm{rpm}$. Since operation at such high speeds inevitably imposes constraints on the rotor dimensions, a high power density is usually required to meet the performance specification. Thus, the generator will generally be subjected to very high levels of mechanical, electrical and thermal stress.

A key consideration during the electromagnetic and thermal design of such machines is the accurate prediction of the stator iron loss, since this can constitute a significant proportion of the total generator loss. This is essential for selecting the most appropriate stator lamination material and geometry, and for specifying the cooling requirements. This paper investigates the stator iron loss in a representative PM generator design, which has a continuous power rating of $1.5 \mathrm{MW}$ and a fixed operating speed of $20000 \mathrm{rpm}$. A cross-section of the machine is shown in Fig. 1, while Table I lists the leading dimensions and other key design parameters. As shown in Fig. 1, in order to counteract the large centrifugal force, the rotor magnets are contained within a high-strength carbon-fiber sleeve.

Compared to most conventional high-power electrical machines, the foregoing generator design has two distinctive fea-

Manuscript received October 16, 2003. This work was supported by QinetiQ and the U.K. Engineering and Physical Sciences Research Council.

The authors are with the Department of Electronic and Electrical Engineering, The University of Sheffield, Sheffield S1 3JD, U.K. (e-mail: g.jewell@sheffield.ac.uk; elp98jjp@sheffield.ac.uk; d.howe@sheffield.ac.uk).

Digital Object Identifier 10.1109/TMAG.2004.832172

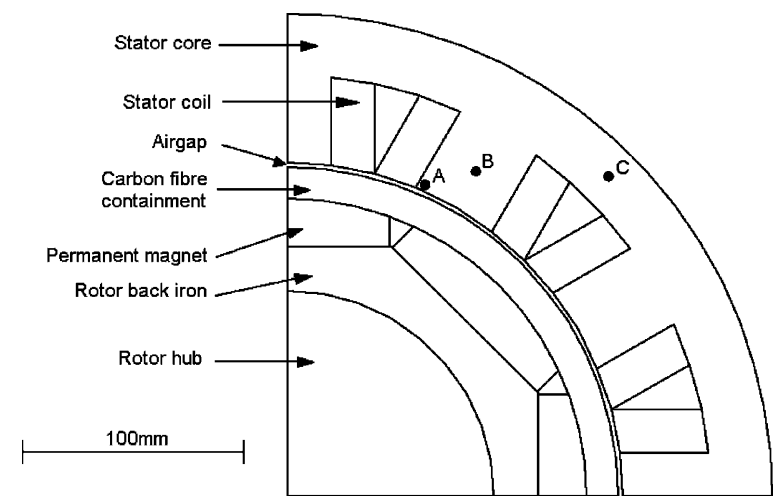

Fig. 1. Cross section of $1.5 \mathrm{MW}, 20000 \mathrm{rpm}$ permanent magnet generator.

TABLE I

GENERATOR DESIGN PARAMETERS

\begin{tabular}{lclc}
\hline Phases & 3 & Rotor outer diameter & $300 \mathrm{~mm}$ \\
\hline DC link voltage & $800 \mathrm{~V}$ & Containment thickness & $14.4 \mathrm{~mm}$ \\
\hline Axial length & $225 \mathrm{~mm}$ & Mechanical airgap & $2 \mathrm{~mm}$ \\
\hline Stator slots & 12 & Magnet thickness (at centre) & $22 \mathrm{~mm}$ \\
\hline Rotor poles & 8 & Magnet pole-arc (outer dia.) & $40^{\circ} \mathrm{mech}$ \\
\hline Stator outer diameter & $440 \mathrm{~mm}$ & Stator bore diameter & $304 \mathrm{~mm}$ \\
\hline Stator slot depth & $40 \mathrm{~mm}$ & Stator back-iron thickness & $28 \mathrm{~mm}$ \\
\hline Coils per phase & 4 & Permanent magnet material & $\mathrm{NdFeB}$ \\
\hline Turns per coil & 2 & Magnet remanence at 20 $20^{\circ}$ & $1.18 \mathrm{~T}$ \\
\hline $\begin{array}{l}\text { Tooth pitch to slot } \\
\text { pitch ratio }\end{array}$ & 0.5 & $\begin{array}{l}\text { Total active mass (excl. casing } \\
\text { and rotor hub) }\end{array}$ & $179 \mathrm{~kg}$ \\
\hline \hline
\end{tabular}

tures which have a significant influence on the magnitude of the iron loss. Firstly, it has a comparatively low airgap flux density as a consequence of the large effective magnetic airgap introduced by the carbon-fiber containment. For this particular combination of rotor diameter and rotational speed, and with sintered $\mathrm{NdFeB}$ magnets, the maximum achievable airgap flux density is only $\sim 0.4 \mathrm{~T}$ in order to ensure that the mechanical stress in the carbon-fiber remains within its service rating of $1 \mathrm{GPa}$.

Secondly, at the rated speed of $20000 \mathrm{rpm}$, the fundamental frequency of the stator flux density variation is $1333 \mathrm{~Hz}$. Although employing 8-poles would appear to be undesirable in terms of iron loss, it is necessary to employ such a high pole number in this generator in order to achieve the required voltage regulation with load current, which, in turn, enables the generator to be connected to a $800 \mathrm{~V}$ DC link by means of a simple uncontrolled bridge rectifier. It is well known that the use of such a rectifier, although offering advantages in terms of efficiency and ruggedness, will produce significant current harmonics and will hence increase the iron loss [1]. 
TABLE II

Material Properties and IRON LOSS COEFFICIENTS FOR STATOR LAMINATION MATERIALS

\begin{tabular}{|c|c|c|c|c|}
\hline & V300 & NO20 & NO12 & $10 \mathrm{EX900}$ \\
\hline Thickness (mm) & 0.35 & 0.20 & 0.127 & 0.10 \\
\hline$\overline{R e s i s t i v i t y ~}(\Omega \mathrm{m})$ & 45 & 52 & 52 & 82 \\
\hline Density $\left(\mathrm{kg} / \mathrm{m}^{3}\right)$ & 7650 & 7650 & 7650 & 7490 \\
\hline $\begin{array}{l}\text { Flux density at } \\
1000 \mathrm{~A} / \mathrm{m}\end{array}$ & 1.45 & 1.45 & 1.45 & 1.29 \\
\hline $\begin{array}{l}\text { Loss at } 0.5 \mathrm{~T}, \\
1333 \mathrm{~Hz}(\mathrm{~W} / \mathrm{kg})\end{array}$ & 71.0 & 38.5 & 15.9 & 7.7 \\
\hline $\begin{array}{l}\text { Loss at } 1.0 \mathrm{~T}, \\
1333 \mathrm{~Hz}(\mathrm{~W} / \mathrm{kg})\end{array}$ & 261.1 & 134.4 & 53.0 & 27.2 \\
\hline $\mathrm{K}_{\mathrm{h}}$ & $17.9 \times 10^{-3}$ & $17.2 \times 10^{-3}$ & $19.3 \times 10^{-3}$ & $8.8 \times 10^{-3}$ \\
\hline $\mathrm{a}$ & 0.84 & 1.21 & 1.25 & 2.05 \\
\hline $\mathrm{b}$ & 1.02 & 0.85 & 1.05 & 0.15 \\
\hline$\overline{\mathrm{K}_{\text {exc }}}$ & $2.0 \times 10^{-4}$ & $2.5 \times 10^{-4}$ & $2.0 \times 10^{-4}$ & $1.7 \times 10^{-4}$ \\
\hline
\end{tabular}

These features inevitably influence the selection of the stator lamination material. Thus, although it is rarely considered as an alternative to grades of $3 \%$ Silicon Iron in large electrical machines, because of its lower saturation flux density and its higher cost, the merit of employing 6.5\% Silicon Iron is considered, since its higher electrical resistivity is likely to offer significant benefits at such a high fundamental frequency. Further, its lower saturation flux density is unlikely to be a significant drawback in this application because of the relatively low airgap flux density. Moreover, the stator has a comparatively small mass for such a high power, high specific cost machine, viz. $95 \mathrm{~kg}$. Thus, it is somewhat easier to absorb the higher lamination material cost than might be the case for other electrical machines.

The performance of four nonoriented grades of Silicon Iron lamination materials, viz. three grades having a nominal Silicon content of 3\% (NO12 and NO20 from Cogent-Power Ltd and V300 from Thyssen-EBG) and a high performance $6.5 \%$ Silicon Iron (10EX900 Super E core from NKK) is evaluated. The key physical, magnetic and electrical properties of these materials, which were derived from a combination of manufacturer's data and measurements on test samples, are given in Table II.

\section{IRON LOSS CALCULATION}

The first stage in the calculation of the magnetic field distribution within the stator is the determination of the phase current waveforms at rated load. This was obtained from an electrical circuit model of the generator and bridge rectifier formulated within the SABER simulation environment. The generator was represented by its open-circuit emf in series with the phase inductance, both of which were derived from finite element analyzes, while the rectifier was based on a standard SABER component model.

Fig. 2 shows the finite element predicted induced emf waveform at $20000 \mathrm{rpm}$ together with the phase current waveform when the machine is supplying rated-load via a 3-phase uncontrolled bridge rectifier. There was negligible difference between the emfs predicted for the 4 stator lamination materials, which confirms that the stator flux density is well below the saturation level for $6.5 \%$ Silicon Iron, and that the large effective magnetic airgap makes the stator flux relatively insensitive to the difference in permeability exhibited by the 4 lamination materials. The finite element predicted self- and mutual-phase inductances

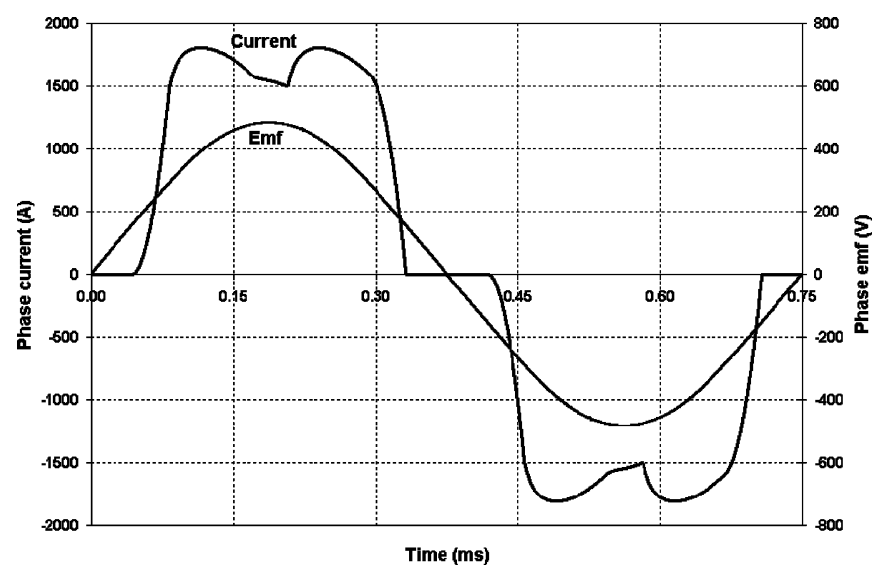

Fig. 2. Predicted open-circuit phase emf, and current at $20000 \mathrm{rpm}$ and 1.5 MW.

TABLE III

HARMONIC CONTENT IN PHASE CURRRENT WAVEFORM

\begin{tabular}{c|c}
\hline Harmonic & $\begin{array}{c}\text { Magnitude (\% of } \\
\text { fundamental) }\end{array}$ \\
\hline $5^{\text {th }}$ & 22.4 \\
\hline $11^{\text {th }}$ & 6.3 \\
\hline $13^{\text {th }}$ & 3.1 \\
\hline $17^{\text {th }}$ & 2.2 \\
\hline $23^{\text {rd }}$ & 1.1 \\
\hline $25^{\text {th }}$ & 0.5 \\
\hline $29^{\text {th }}$ & 0.8 \\
\hline
\end{tabular}

are $10.2 \mu \mathrm{H}$ and $-4.0 \mu \mathrm{H}$, respectively, at the rated phase current of $1800 \mathrm{~A}$, again with no discernable difference between the different stator lamination materials. It will be noted that, the foregoing are average inductance values since there is a small degree of saliency in the rotor, which results in a 3.5\% variation in both the self- and mutual-inductances with rotor angular position.

Table III shows that significant harmonics result in the current waveform when the generator is connected to the DC link by a simple bridge rectifier.

The predicted current waveform was used in a series of magnetostatic field calculations encompassing one complete electrical cycle, from which flux density waveforms within each finite element in the stator mesh were determined. At rated load, it was necessary to perform separate field calculations for the $3 \%$ and $6.5 \%$ grades of Silicon Iron since the armature reaction field is sufficiently large for regions of the stator teeth to experience levels of flux density at which there are significant differences in the lamination magnetization characteristics, i.e., $>1.3$ T. By way of example, Fig. 3 shows predicted waveforms for the radial and tangential components of flux density at location A in the stator (as defined in Fig. 1) which results with both $3 \%$ and $6.5 \%$ Silicon Iron laminations. This particular location, at the edge of a stator tooth, exhibits the highest saturation, and, hence, the largest change in flux density waveform with lamination material. In contrast, locations B and C in Fig. 1 experience an essentially alternating field at a moderate flux density. Hence, negligible difference is observed between the flux density waveforms which result with the various lamination materials.

Once the flux density waveforms within each finite element have been determined, the resulting iron loss can be calculated using well established and validated loss models [2]. The loss 


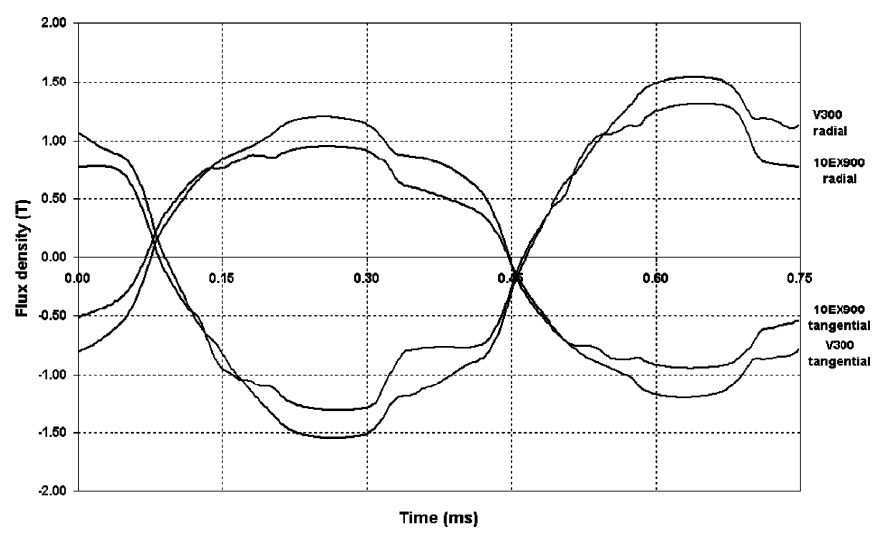

Fig. 3. Finite element predicted flux density waveforms at location A at 1.5 MW and $20000 \mathrm{rpm}$.

density, in any given element due to any arbitrary flux density variation, can be determined by summing of the hysteresis, excess and classical eddy current loss components

$$
\begin{aligned}
P_{F e}=k_{h} \hat{B}^{a+b \hat{B}} f+\frac{\sqrt{\sigma}}{\delta_{F e}} K_{\text {exc }} & \frac{1}{T} \int_{T}\left|\frac{d B}{d t}\right|^{1.5} d t \\
& +\frac{\sigma d^{2}}{12 \delta_{F e}} \frac{1}{T} \int_{T}\left|\frac{d B}{d t}\right|^{2} d t(\mathrm{~W} / \mathrm{kg})
\end{aligned}
$$

where $f$ is the fundamental frequency, $\sigma$ is the electrical conductivity, $\delta_{\mathrm{Fe}}$ is the density, and $B$ is the instantaneous flux density. The coefficients $\mathrm{K}_{\mathrm{h}}, \mathrm{K}_{\mathrm{exc}}, a$ and $b$ can be determined from either Epstein ring or single sheet tests, and were assigned the values shown in Table I for the various lamination materials. In order to account for regions in which there is a significant rotational flux density, the loss in each element was calculated by summing the loss determined for the radial and tangential flux density components separately [3]. Although this is an approximation, this simplification has been adopted widely. In order to cater for the existence of any minor-loop flux density excursions as a result of the armature reaction field, the technique proposed by Lavers for correcting the hysteresis component of loss [4] were adopted. The total hysteresis loss for a flux density waveform having a peak value $\mathrm{B}_{\mathrm{p}}$ and containing $\mathrm{n}$ minor-loops each of magnitude $\Delta B_{i}$ is given by

$$
W_{h, \text { total }}\left(B_{p}\right)=W_{h}\left(B_{p}\right) \cdot\left(1.0+k \cdot \frac{1}{B_{p}} \sum_{i=1}^{n} \Delta B_{i}\right)
$$

where the parameter $k$ was assigned a value of 0.65 for all 4 lamination materials.

The predicted no-load and full-load stator iron loss which result with the different stator lamination materials are summarized in Table IV. As might be expected, given the nature of the flux density waveforms, a considerable reduction in iron loss can be achieved by employing 10EX900 in this particular generator, without compromising the electrical output power. It is pertinent to consider the influence of the armature reaction field on the loss, in view of the high frequency harmonic content. In this regard, the 10EX900 is particularly useful, as is illustrated by the fact that in going from no-load to full-load the iron loss increases by $56 \%$ when the generator is equipped with V300
TABLE IV

PREDICTED IRON LOSS ON NO-LOAD (NL) AND FULL-LOAD (FL)

\begin{tabular}{l|c|c|c|c|c|c|c|c}
\hline \multirow{2}{*}{$\begin{array}{l}\text { Component } \\
\text { of loss }\end{array}$} & \multicolumn{2}{|c|}{ V300 } & \multicolumn{2}{c}{ NO20 } & $(0.2 \mathrm{~mm})$ & \multicolumn{1}{c}{ NO12 $(0.127 \mathrm{~mm})$} & \multicolumn{2}{c}{10 EX900 } \\
\cline { 2 - 9 } & NL & FL & NL & FL & NL & FL & NL & FL \\
\hline $\begin{array}{l}\text { Hysteresis } \\
(\mathrm{kW})\end{array}$ & 1.91 & 2.44 & 1.64 & 2.12 & 1.75 & 2.33 & 0.72 & 0.97 \\
\hline $\begin{array}{l}\text { Excess }(\mathrm{kW}) \\
(\mathrm{kW})\end{array}$ & 1.31 & 1.83 & 1.52 & 2.13 & 1.22 & 1.70 & 0.83 & 1.16 \\
\hline $\begin{array}{l}\text { Eddy current } \\
(\mathrm{kW})\end{array}$ & 7.50 & 12.41 & 2.12 & 3.50 & 0.85 & 1.42 & 0.34 & 0.56 \\
\hline Total(kW) & $\mathbf{1 0 . 7 2}$ & $\mathbf{1 6 . 6 8}$ & $\mathbf{5 . 2 8}$ & $\mathbf{7 . 7 5}$ & $\mathbf{3 . 8 2}$ & $\mathbf{5 . 4 5}$ & $\mathbf{1 . 8 9}$ & $\mathbf{2 . 6 9}$ \\
\hline
\end{tabular}

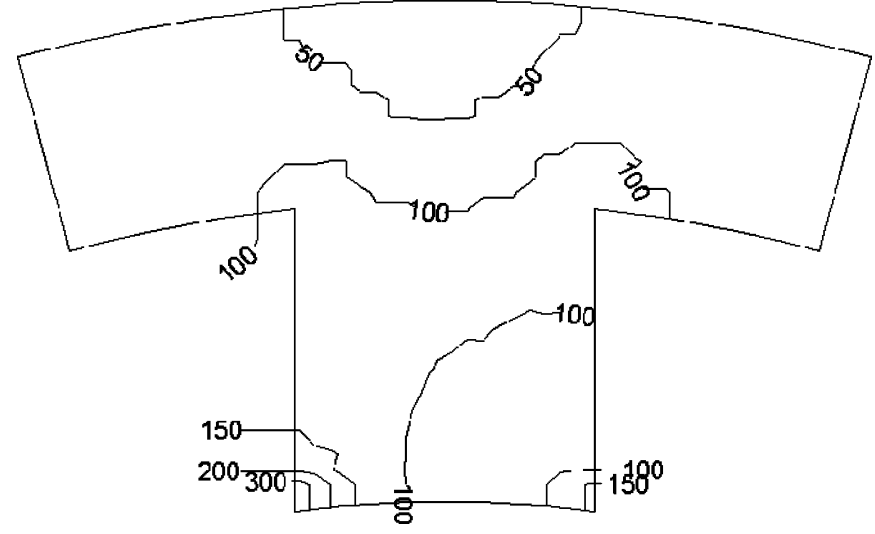

Fig. 4. Contours of iron loss density over 1 tooth pitch of N020 lamination.

laminations and by only $42 \%$ when 10EX900 laminations are employed.

The need to employ detailed finite element analysis rather than simple analytical methods is highlighted by considering the distribution of the iron loss in the NO20 stator laminations at rated-load, Fig. 4. Although the average loss density is 94 $\mathrm{W} / \mathrm{kg}$, localized regions near the edge of a tooth (the direction of rotation being clockwise) experience a considerably higher loss density.

\section{CONCLUSIONS}

The potential benefit, in terms of reduced iron loss, by employing $6.5 \% \mathrm{SiFe}$ laminations in a representative high speed, high power permanent magnet generator, whose output is rectified by a simple bridge rectifier, has been quantified. Whilst it is shown that reducing the thickness of $3 \% \mathrm{SiFe}$ laminations is highly beneficial, the adoption of $6.5 \% \mathrm{SiFe}$ laminations results in a significant reduction in iron loss.

\section{REFERENCES}

[1] H. Polinder and M. J. Hoeijmakers, "Modeling of iron losses in highspeed PM machines," in Proc. Int. Conf. Electrical Machines (ICEM 2000), Helsinki, Finland, August 28, 2000, pp. 637-641.

[2] G. Bertotti, A. Boglietti, M. Chiampi, D. Chiarabaglio, F. Fiorillo, and M. Lazzari, "An improved estimation of iron losses in electrical machines," IEEE Trans. Magn., vol. 27, no. 6, pp. 5007-5009, 1991.

[3] K. Atallah, Z. Q. Zhu, and D. Howe, "The prediction of iron losses in brushless permanent magnet DC motors," in ICEM92, Manchester, U.K., 1992, pp. 814-818.

[4] J. D. Lavers, P. P. Biringer, and H. Hollitscher, "A simple method of estimating the minor loop hysteresis loss in thin laminations," IEEE Trans. Magn., vol. 14, pp. 386-388, 1978. 